\title{
Discord to Support Synchronous Communication in Distance Learning
}

\begin{abstract}
Barnad Barnad
Polytechnic of UBAYA Surabaya

"Corresponding Email: hl.poltekubaya@gmail.com

ABSTRACT

Distance learning is an option for the learning process during the Covid-19 pandemic. Most education providers in Indonesia are still low in understanding and experience in implementing distance learning. Polytechnic of UBAYA Surabaya has implemented distance learning in the two semesters. The learning process that is carried out is mostly the same as face-to-face learning by only modifying how to deliver learning material using information and communication technology such as WhatsApp, email, Zoom meeting, or Google meet. The research was conducted using a narrative research method based on the summary results of students' feedback about the implementation of distance learning carried out for two semesters. The description in this paper aims to offer alternative solutions to improve the distance learning process's performance and use Discord software to support effective and efficient synchronous communication to make learning outcomes.
\end{abstract}

Keywords: Effective, Efficient, Distance Learning, Synchronous Communication

\section{INTRODUCTION}

Article 31, paragraph 1 of the 1945 Constitution states that every citizen has the right to education, and paragraph 2 states that every citizen is obliged to attend primary education. The government is obliged to pay for it. The obligation to participate in formal education on the primary level is the government's effort so that citizens who have completed this level can continue to a higher level. We believe that the formal education adopted by every Indonesian citizen can improve the welfare of every actor. Therefore, every family in Indonesia makes every effort to learn from the lowest to the highest level.

The main activity carried out in the educational process is learning. There is a process of interaction between students, educators, and learning resources owned in a learning environment in every learning activity. Learning activities in formal education are carried out in a structured manner according to the curriculum set by that the students received. Students are obliged to complete all the learning that has been determined with a pass status.

In general, education providers in Indonesia carry out face-to-face learning activities in a classroom. This form of learning requires direct (synchronous) interaction between educators and students in delivering learning material. Furthermore, an educator can monitor students' body language (movements) and control the classroom atmosphere during the learning process. Each student can interact directly with the learning material provided and can respond directly to the explanation given by the educator or fellow students.

In mid-December 2019, the Covid-19 outbreak was first identified in the Wuhan-China area, and since then, the outbreak has still spread throughout the world. Data from covid19.who.int as of March 9, 2021, worldwide there were 118,745,336 confirmed cases of Covid-19, and 2,634,370 deaths. While in our country (Indonesia), there were 1,410,134 confirmed cases and 38,229 deaths. One of the efforts to prevent the spread of this virus by following the recommendations of the World Health Organization (WHO) is to stay at home and, are forced to do activities outside the home to keep a minimum distance of 1 meter, wear a mask and wash hands as often as we can and after finish the activity. Many countries, including Indonesia, have stipulated that their citizens stay at home by implementing Work From Home (WFH).

The Indonesian government enforces the WFH policy for all community activities, including elementary to tertiary education activities carried out from home. All education providers carry out the entire learning process online. The procedure for education providers to carry out online learning is a new paradigm. So far, most of the learning process's implementation is done face-to-face in class. Lack of understanding and experience in doing distance learning makes the learning process the same as face-to-face learning in class. The difference is delivering learning material using communication technology devices, such as WhatsApp, email, Google meets, Zoom meetings, etc. 
Polytechnic of UBAYA is a vocational college that implements a one-week learning schedule of 38 lecture hours. The face-to-face learning process is carried out from Monday to Thursday, starting at 07:00 - 1:20 P.M and Friday from 07:00 - 11:20 A.M. The lecture schedule is hectic but still provides a conducive atmosphere for students to carry out the learning process. Each student enthusiastically undergoes the learning process because each student is given space for activities and interacts directly with other students and the learning facilities and extracurricular activities provided by the campus.

The application of the distance learning process to limit each person's interaction will affect the quality of learning of each student if the learning process is carried out as in normal conditions (face to face). This statement is the initial hypothesis of this study. To answer this hypothesis, the authors conducted narrative research on students as the data used for research is the summary data on students who have done distance learning and input from the learning process using Discord software as a means of synchronous communication. The research results' follow-up can be used as study material (recommendations) for alternative solutions for distance learning formats and the choice of synchronous communication technology appropriate and effective, and efficient in supporting the learning process that resembles face-to-face learning. It is hoped that this alternative solution can provide guarantees for students to achieve the subjects' learning outcomes that the study program has determined.

The method used to measure the success of learning outcomes is by using a survey method in the form of a questionnaire. Questionnaires were distributed to students who had used Discord to support synchronous communication technology in their learning process.

\section{LITERATURE REVIEW}

Education is a conscious and planned effort to create an atmosphere of learning and the learning process. Students actively develop their potential to have religious-spiritual strength, self-control, personality, intelligence, noble character, and skills needed by themselves, society, nation, and state [1]. In Indonesia, every citizen who takes formal education must be done in primary education stages, from secondary education to higher education. Formal education is carried out in a structured manner following the government and education providers' rules. The learning processes must cover the cognitive, psychomotor, and affective domains [2]. The results of the learning process carried out must be able to foster the value of the soft skills of each student. Sailah [3] states that graduate users or the wider community want undergraduate graduates who have broad knowledge, have the skills to use their expertise in the world of work, and behave according to ethics and norms prevailing in the society. Berthal [4] states that soft skills are personal and interpersonal behaviors that develop and maximize human performance. Some examples of the attributes of soft skills that are prioritized in the world of work are initiative, ethics/integrity, critical thinking, willingness to learn, commitment, motivation, enthusiasm, reliability, oral communication, and creativity.

Education is a series of communication activities that aim between adult humans and students face-to-face or by using the media to help complete development [5]. Communication that is carried out involves understanding how peoples behave in creating, exchanging, and interpreting messages [6]. Berelson and Steiner [7] state that communication is the transmission of information, ideas, emotional skills, and so on, using symbols in words, pictures, figures, graphics, etc.

Distance learning is the learning alternative chosen to minimize interaction in the teaching and learning process. Distance education is distance learning by utilizing communication technology (internet) as a means of learning. Distance education is the structuring methodology and managing dialogue between teacher and learner to bridge that gap through communications technology [8]. Distance education, on the other hand, is less a philosophy and more a method of education. Students can study in their own time, at the place of their choice (home, work or learning center), and without faceto-face contact with a teacher. Technology is a critical element of distance education [9]. Distance learning provides greater flexibility for students to work at their own pace and review work as needed. Students can access your course material at the times that work best for them, which is essential for students who may have irregular work schedules[10].

In distance learning, communication is an essential element in the learning process. Communication in distance learning can be synchronous communication, namely real-time communication in interactions between message givers and message recipients such as virtual classrooms, face-to-face chat rooms, or communication by telephone. Another alternative for synchronous communication can be using software such as Discord Servers. This software is efficient because it is available in the form of free software without any facility restrictions and is effective for synchronous communication because this software provides the facility to create several classrooms. At each school, several forum group discussions (FGD) can be made. An admin is responsible for managing the classroom and setting restrictions and granting privileges for each user who joins the classroom. Each user who has joined this facility can perform activities: Text Channel, Voice Chat, Video Chat, Share Screen, and Watch a Screen Share Streaming. The facilities provided can be used for oneto-one communication if the message is addressed to a particular user-selected or for one-to-many communication if the message is delivered to all users in a classroom [11]. Another communication that can be used in the learning process is asynchronous communication, which is when a message is delivered without expecting a direct response from the recipient of 
the message, such as email. In asynchronous communication, the speaker and audience do not cooccur. The resulting interaction between individuals using different learning theories, styles and activities, and technologies can create learners' vibrant communities [12].

\section{METHODS}

Business Simulation courses in normal (offline) conditions are carried out in office laboratories. Students are divided into six groups, and each group is a business unit and has its own office space to complete work. Each student becomes office personnel and has duties according to their position, namely, a manager, marketing staff, finance staff, inventory staff, and administrative staff. Every office personnel needs office equipment and oral and written communication to complete office work by the educator's instructions.

At present, the learning process is carried out from their respective residences (WFH). The work and communication process uses equipment that is not of the same quality so that the results of the work carried out are not optimal. The author's solution to overcoming work barriers in this learning process is by utilizing Discord Servers as a means of synchronous communication in writing, voice, and video [11]. The use of Discord Server to support the learning process is being used for the first time at Polytechnic of UBAYA. Therefore, the writer made this learning to format the object of narrative research. The author is directly involved in every learning implementation to observe work activities carried out by each student. The results of the observations are used as research data and then analyzed to conclude.

Preparation before the research was to configure Discord Servers so that they could serve as virtual offices. The configuration is,

1. Create six Text Channels on Discord Servers (Figure 1). Text channels are used as virtual offices to perform internal synchronous communication activities between office personnel.

2. They are creating a Text Channel for managers to communicate synchronously between business units.

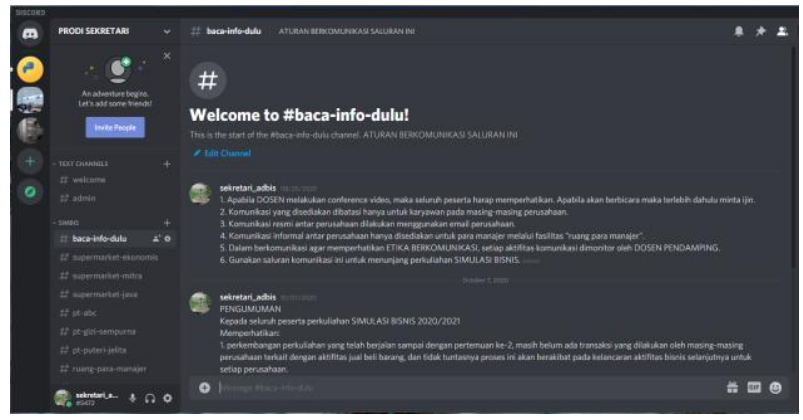

Figure 1. Discord Server for synchronous communication facilities between business units
3. Set the role of each student who has joined Discord Servers. According to the Text Channel prepared, the functions are arranged so that synchronous communication for each office personnel can only be done on each Text Channel. Specifically for managers, they are given additional roles to communicate using the manager's Text Channel. The part of educators is more arranged so that they can interact with all Text Channels.

4. They are distributing Business Simulation Application Programs (Figure 2.). When the Instruction button is clicked, you will hear instructions invoice format-different-sounding voice instructions for each class schedule. Therefore, any work that is created must be completed before the weekend meeting. Every office personnel must listen to the instructions given as a reference in carrying out their assignments.

Each office personnel performs work based on the instructions obtained from the Business Simulation Application Program. At each meeting, the instructions given are different for each personnel. Documents on the results of the work that has been completed must be consulted with the teaching correcting them. Consultation process using Discord Servers. The correct form is used to carry out the following work process. If the condition is related to other business units, the document submission is made through the managers' Text Channel. Business process flow between teams (Figure 3).

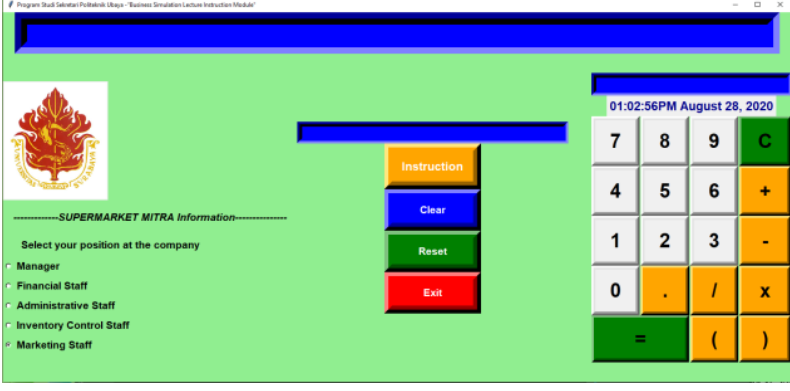

Figure 2. Business Simulation Application Program for listening to the job instructions to do.

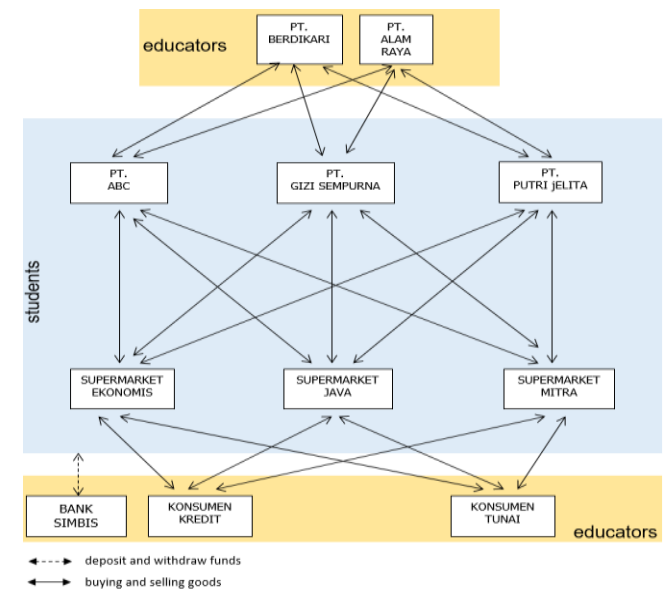

Figure 3. The business process of buying and selling transactions between business units. 


\section{DATA ANALYSIS}

The narrative research conducted aims to recommend effective and efficient synchronous communication in the online learning process. The data used are feedback on the online learning process carried out for 2 semesters using communication technology such as WhatsApp, email, Zoom meetings, Google meet, and other technologies. The feedback data collection process is carried out online by surveying each student. The data collection process is carried out after the learning process of one semester ends. The summary of the feedback provided by students can be seen in Table 1 .

\section{DISCUSSION}

Table 1 is a summary of student responses about the online learning process that has been implemented. Students are not maximal in undergoing the learning process due to network constraints and inappropriate methods used. In general, educators apply the teacher center learning (TCL) model, such as face-to-face learning in classrooms. The communication channels used are synchronous communication using communication devices: zoom meetings, google meet, WhatsApp. The distance learning process should be carried out flexibly in the time and place of learning [13]. Students are fully responsible for studying learning material independently.

Table 1 Summary of students' feedback on the distance learning process at Polytechnic of UBAYA

\begin{tabular}{cl}
\hline No & \multicolumn{1}{c}{ Details of Student Feedback } \\
\hline 1. & The delivery method must be varied so that students do not get bored and sleepy quickly during lectures. \\
2. Teaching methods tend to be monotonous and less varied. \\
3. Reduce the explanation from PowerPoint slides because we can read the material ourselves. \\
4. Expand the practice of the case and provide a way to solve it appropriately. \\
5. Need to increase understanding of technology to help how to use technology tools. \\
6. Teaching alone without PowerPoint slides made some students even more bored because they only listened to \\
7. lectures. \\
Shen the lesson is over, can we send the recorded video results during the lecture because our network \\
sometimes breaks up, so we don't have time to hear it?
\end{tabular}

Source: The direction Director Polytechnic of UBAYA at the Lecturer Coordination Meeting.

Distance learning forms are not easy to be implemented because they have to prepare hardware and software so that the learning process runs well. Most education providers in our country carry out the distance learning process because of the compelling circumstances resulting from the Covid-19 outbreak, so that appropriate hardware and software to support distance learning are not necessarily available. One shortterm solution that education providers can do is produce each learning material in the multimedia form [14]. The learning materials that are made are also equipped with modules equipped with case examples and assignment questions to improve students' cognitive and psychomotor abilities. All of the learning material is given to students before discussing the material is carried out so that students can learn it first. If students do not understand or want to know more about the material provided, they can study it again at another time and anywhere [9]. The lecture schedule that the study program has determined can be used to carry out discussion activities or question and answer activities about learning materials discussed using synchronous communication technology such as Zoom, Google meet, WhatsApp [7], [8].

The learning to model that implement's student center learning (SCL) and each student's activities interact with one another, synchronous communication with teleconferencing devices (Zoom, WhatsApp) is not practical because the facilities are only for video communication and inefficient. After all, the costs are expensive (subscription fee and internet quota). The Business Simulation course is an example of a method that applies SCL. Each student interacts with each other to carry out business transactions within business units and between business units. In the learning process, courses as a means of synchronous communication between students use Discord Servers software. This software is being used for the first time in distance learning at Polytechnic of UBAYA. Table 2 results from the feedback given by students at the end of the Business Simulation lecture semester.

Table 2 Student feedback on Business Simulation courses

\begin{tabular}{|c|c|c|}
\hline No & $\begin{array}{l}\text { Details of Student Feedback } \\
\end{array}$ & Values of Soft Skills \\
\hline 1. & $\begin{array}{l}\text { We can operate Discord for chatting, voice calls, screen sharing, and video } \\
\text { calls with a few internet quotas. }\end{array}$ & $\begin{array}{l}\text { Work on time, work with } \\
\text { teams, be a leader, }\end{array}$ \\
\hline 2. & Discord can still be used well on laptops that have limited storage media. & communicate verbally, be \\
\hline 3. & $\begin{array}{l}\text { Discord is used as a facility for conducting discussions and meetings, sending } \\
\text { documents, video calls, one-to-one and one-to-many audio conferencing. }\end{array}$ & responsible for work \\
\hline 4. & We can be used on various devices such as smartphones, laptops, and PCs. & \\
\hline 5. & We can know the status of the user, whether they are online or offline. & \\
\hline
\end{tabular}


Table 2 illustrates that the Discord Servers software can help students communicate synchronous online learning in Business Simulation courses. Students can carry out business activities by a predetermined field of work. Another aspect that students get with online learning in this course is the formation of soft skill values, such as working on time, working with teamwork, being a leader, communicating verbally, being responsible for work. The importance of these soft skills will be helpful in the world of work [3].

\section{CONCLUSIONS}

The use of appropriate synchronous communication methods and facilities in the distance learning process will result in an effective and efficient learning process so that every student's learning outcomes can be achieved.

Discord Server is a suitable software to support synchronous communication, both privately (one-to-one) and public (one-to-many). The distance learning process's effectiveness and efficiency can be achieved by using Discord-Server, which chatted, sharing screen, voice call, and video call facilities. All of these facilities can be used to conduct discussions between students to be actively involved in the learning process.

\section{AUTHORS' CONTRIBUTIONS}

Distance learning is currently the main form of learning used today. Hopefully, with this study's results, we can choose synchronous communication facilities and appropriate learning media so that the learning process is carried out effectively and efficiently.

\section{ACKNOWLEDGMENTS}

On this occasion, the author would like to thank the Director Polytechnic of UBAYA, who has allowed the author to do research. The Secretarial Study Program students have been the inspiration in this research.

\section{REFERENCES}

[1] President of Indonesia, "Constitution No. 2 of 1989 Concerning the National Education System," 2003.

[2] Anderson, "A Taxonomy for Learning, Teaching, and Assessing: A Revision of Bloom's Taxonomy of Education Objectives." David Mckay Company, Inc, New York, 2001.

[3] Sailah I., "Pengembangan soft skills dalam proses pembelajaran di perguruan tinggi." Direktorat Akademik DirJen Dikti, Departemen Pendidikan Nasional, Jakarta, p. 52, 2008.

[4] Muqowin, "Pengembangan Soft Skills Guru." Pedagogia, Yogyakarta, 2012.

[5] Zahara I., "Dasar-Dasar Kependidikan." Angkasa, Bandung, 1997.

[6] Littlejohn and S. W. Foss, Theories of Human
Communication (Ninth Edition ed.). Belmont: Thomson Learning, 2008.

[7] Mulyana D., "Ilmu Komunikasi: Suatu Pengatar." Remaja Rosdakarya, Bandung, 2005.

[8] M. G. Moore and W. C. Diehl, Handbook of Distance Education, 4th Editio. New York: Routledge, 2019.

[9] A. W. Bates, Technology, E-learning and Distance Education, 2nd ed. London: Routledge, 2005.

[10] Stauffer B., "What's the Difference Between Online Learning and Distance Learning? " 2020. [Online]. Available: https://www.aeseducation.com/blog/onlinelearning-vs-distance-learning.

[11] "teaching-with-discord-a-beginners-guidewritten-by-a-beginner," $2020 . \quad$ [Online]. Available:

https://teachingpals.wordpress.com/2020/08/13/t eaching-with-discord-a-beginners-guidewritten-by-a-beginner/.

[12] T. Anderson, "The Virtual Conference: Extending Professional Education in Cyberspace," Int. J. Educ. Telecommun., vol. 2, no. 2, pp. 121-135, 1996.

[13] S. Layton, "What's the Difference between Online Learning and Distance Learning?," Applied Educational Systems, 2017. [Online]. Available:

https://www.aeseducation.com/blog/2013/09/dif ference-between-online-learning-and-distancelearning.

[14] Barnad, "Learning Material in Multimedia Supporting Online Learning," Psychol. Educ., vol. 58, pp. 5988-5994, 2021, DOI: https://doi.org/10.17762/pae.v58i2.3076. 